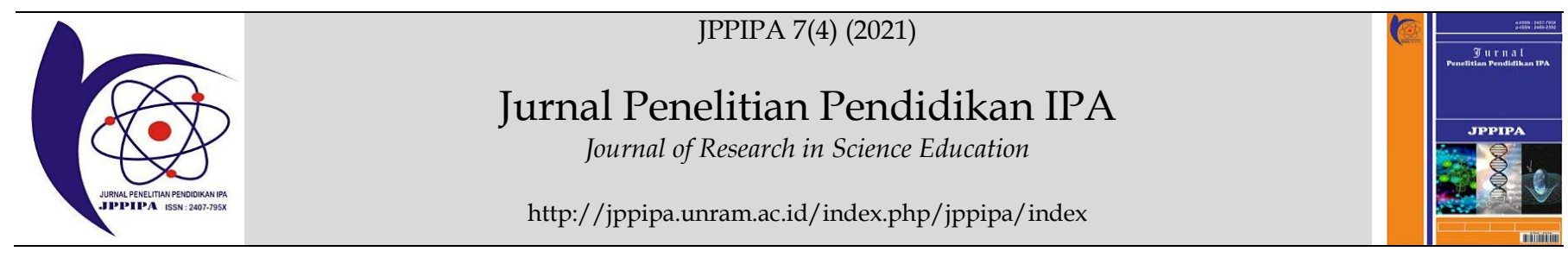

\title{
Analysis of the Need for Android Based Mobile Learning Development to Improve Student Science Literations
}

\author{
Ulia Anisatur Rosidah" ${ }^{*}$, Putut Marwoto ${ }^{1}$, Bambang Subali ${ }^{1}$ \\ ${ }^{1}$ Science Education, Postgraduate Program, Universitas Negeri Semarang, Semarang, Indonesia.
}

DOI: $\underline{10.29303 / \text { ippipa.v7i4.805 }}$

\section{Article Info}

Received : June $18^{\text {th }}, 2021$

Revised : August 14th 2021

Accepted: October 7th, 2021

\begin{abstract}
Science learning in Indonesia has not succeeded in increasing scientific literacy skills, as indicated by the decreasing international ranking from year to year. One of the efforts made to improve scientific literacy is using Android-based learning media. This study aims to analyze the need for the development of instructional media to improve students' scientific literacy at MTs Al Uswah Bergas Semarang Regency. This type of research is a descriptive study that is to describes the current situation. The data instruments used were interviews, observation, and questionnaires. The results of the research on the analysis of the needs for learning media based on android showed that $38 \%$ of the 80 students, namely 30 students agreed to develop Android-based learning media, while $29 \%$ of the students showed disagreement, $21 \%$ strongly agreed, and 12\% strongly disagreed. There are aspects of literacy then students including; literacy as mastery of science as knowledge was $63 \%, 66 \%$ as a way of thinking, $62 \%$ of scientific literacy as a way of learning, $62 \%$ of the aspects of mastery of the competence of the interaction of science, technology, and society. Therefore, it is necessary to conduct research on the development of Android-based mobile learning media to improve students' scientific literacy.
\end{abstract}

Keywords: Learning Media; Android Mobile Learning; Science Literacy

Citation: Rosidah, U., Marwoto, P., \& Subali, B. (2021). Analysis of the Need for Android Based Mobile Learning Development to Improve Student Science Literations. Jurnal Penelitian Pendidikan IPA, 7(4), 601-606. doi:https://doi.org/10.29303/ippipa.v7i4.805

\section{Introduction}

According to the 2015 Program for International Student Assessment (PISA), Scientific literacy is the ability to use the relationship of science with scientific issues and ideas as a relative society (OECD, 2015). scientific data literacy is in Table 1.

Table 1. Science Literacy Data for Indonesian Students

\begin{tabular}{lllll}
\hline Study Year & 2006 & 2009 & 2012 & 2015 \\
\hline Average Score & 393 & 383 & 382 & 403 \\
International & & & & \\
Indonesia Rank & 50 & 40 & 64 & 62 \\
Participant Countries & 57 & 65 & 65 & 70 \\
\hline
\end{tabular}

Source: (OECD, 2015).
Table 1 shows that the assessment conducted by PISA reveals that science learning in Indonesia has not succeeded in increasing scientific literacy skills, as indicated by the decreasing international ranking from year to year.

The use of technology and media in learning can foster students' scientific literacy (Kusumawardhani et al., 2019). The use of integrated natural science teaching materials can solve the problem of integrated natural science learning and improve students' digital literacy, both scientific, functional, and visual literacy (Asrizal et al., 2018).

Android-based mobile learning technology is very worthy of consideration for the development of mobile learning media (Haryanto \& Billah, 2020). This is also supported by the popularity of mobile devices,

\footnotetext{
*Email: uliaanisa32@students.unnes.ac.id
} 
which have become the general public's choice (Liu et al., 2015), the increase in the number of ownership of Android mobile learning among students, and the prospect of increasing the number every year.

Technological developments will have a negative or positive impact (AS, 2020). One of the negative impacts on technological development is that it can cause students to be lazy to learn science because the development of technology can make humans ignore the effects of the influence on global humanity. For example, science without ethics can cause environmental and psychological crises. Science and Islam are said to be integrated with each other when they both rely on a belief that basically, both have the same study, design, and purpose. Integration in Islam and science is an attempt to combine the two (Yaqin, 2020). Al-Qur'an motivates its people to love science. The verses of the Qur'an give scientific signals (Badarussyamsi, 2015).

The positive impact of Android-based learning media has been widely reported. Android-based mobile learning media can improve student learning outcomes (Cahyana et al., 2018). In addition, the use of android as a basis for learning media also supports the effectiveness of interaction and communication between teachers and students in the teaching and learning process (Ngabekti et al., 2019). This androidbased media can support independent learning and classroom learning (Wibawa et al., 2020).

Android-based learning media is needed in the natural science learning process (Cahyana et al., 2018). In natural science learning, the development of learning media by utilizing the Android operating system has been successfully developed, including the human hearing system (Billah \& Yazid, 2020), the human respiratory system (Pratama et al., 2020), the human digestive system (Juannita \& Adhi, 2017), and the human optical apparatus system (Sajidan et al., 2020).

Initial observations were made at MTS Al Uswah Bergas, Semarang Regency, especially in learning natural science, the subject of the human excretion system. The findings of the preliminary observations include: teachers still use conventional methods, limited facilities used in the natural science learning process, and a lack of learning media that facilitate understanding and support scientific literacy skills.

The human excretion system is one of the subjects of natural science subjects in grade VIII. In practice, teachers still use the conventional method of textbook-based lectures without interesting learning media and support the improvement of students' scientific literacy. Based on the above explanation, this study aims to analyze the need for developing Android-based mobile learning media on the subject of the human excretion system to improve students' scientific literacy.

\section{Method}

This type of research is a descriptive study that is to describes the current situation. Descriptive research is research with a method to describe a research result (Sugiyono, 2019). The subjects of this study were 35 students of class VIII and a science teacher at MTs Al Uswah Bergas.

The data collection technique was carried out through the following methods: (1) interviews with natural science subject teachers, (2) observation, and (3) direct distribution of questionnaires to class VIII MTs students. Interviews were conducted with teachers who teach natural science subjects to determine responses to the need for natural science learning using Androidbased media integrated scientific literacy and problems that often occur in learning activities.

\section{Result and Discussion}

Observations made at MTs Al Uswah School aim to find out how interested students are in learning natural sciences. Whether students are more interested in using learning media facilitated by school or learning is application. In addition, the purpose of observation is to find out the student's interest in development technology. The results of observations at MTs Al Uswah can be seen in Table 2 .

Table 2. Observation Results at MTs Al Uswah School

\begin{tabular}{lll}
\hline No. & Question & Answer \\
\hline 1 & Facilities at MTs Al Uswah school & Learning facilities used in the natural science learning process include \\
that can be used to support the & classrooms, natural science laboratories, a computer room, a library, and a \\
learning process in schools, especially & school health unit (UKS). The IPA laboratory is usually used as a place for \\
in the field of Natural Science & $\begin{array}{l}\text { practice. There are several teaching aids in natural science laboratories, } \\
\text { including torso, KIT, test tube, dropper, measuring cup, clamp, litmus, and } \\
\text { microscope. In the computer room, there are several computers for internet } \\
\text { access. The library provides books that can be studied, especially natural } \\
\text { sciences. In the UKS room, there is a tensimeter device to measure blood } \\
\text { pressure that can be used in a practicum in science learning about blood } \\
\text { circulation material. }\end{array}$ \\
\end{tabular}




\begin{tabular}{lll}
\hline No. & Question & Answer \\
\hline 2 & $\begin{array}{l}\text { The enthusiasm of students in } \\
\text { participating in learning using } \\
\text { learning media }\end{array}$ & $\begin{array}{l}\text { When the learning process takes place using media that the teacher brings to } \\
\text { the classroom or media in the science laboratory, there are some students who } \\
\text { are enthusiastic about learning, but some students are also confused because } \\
\text { the media is limited in number, which is not proportional to the number of } \\
\text { students. In the UKS room, there is a blood pressure device that can be made } \\
\text { practicum on learning science on blood circulation material. }\end{array}$ \\
\hline 3 & $\begin{array}{l}\text { The use of learning media that uses } \\
\text { Android-based technology in the } \\
\text { learning process in the classroom }\end{array}$ & Learning in the classroom has not used Android-based media. \\
\hline
\end{tabular}

The results of interviews with science subject teachers, which show a list of questions and answers submitted to teachers, can be seen in Table 3 .

Table 3. List of Questions and Answers that are Asked of the teacher.

\begin{tabular}{lll}
\hline No & Questions & Answer \\
\hline 1 & The need for learning media & $\begin{array}{l}\text { The limitations of learning media available in natural science laboratories } \\
\text { do not support all students' understanding, so learning media are needed } \\
\text { that can improve students' understanding. }\end{array}$ \\
\hline 2 & $\begin{array}{l}\text { The knowledgeability of students } \\
\text { towards natural science learning which } \\
\text { is integrated with scientific literacy }\end{array}$ & $\begin{array}{l}\text { Students' knowledge of scientific literacy is just knowing, and for now, the } \\
\text { teacher has not integrated natural science learning with scientific literacy. }\end{array}$ \\
\hline
\end{tabular}

The results of the teacher interviews in Table 3 are also shown by the questionnaire data on the needs of students that students filled in via google form, which has been distributed to all students. The learning media needs of students for learning natural science are shown in Figure 1.

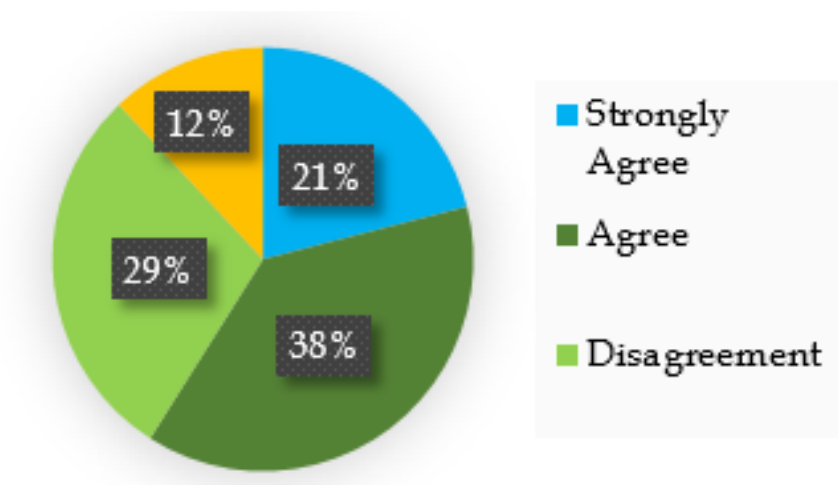

Figure 1. Needs Analysis of Learning Media Based on Android

Based on the results of the questionnaire of class VIII MTs Al Uswah Bergas about the analysis of the needs of android-based learning media, the results showed that $38 \%$ of the 80 students, namely 30 students agreed to develop android-based learning media. This can make them interested in learning natural science lessons and eliminate perceptions about difficulties in learning natural sciences that are integrated with scientific literacy. Students who showed disagreement were $29 \%$ (23 students from 80 students), 21\% (17 students out of 80 students) showed strongly agree to develop Android-based learning media, and 12\% (10 students out of 80 students), $38 \%$ strongly disagree.

The results of distributing questionnaires about scientific literacy abilities were carried out to determine students' ability to learn natural science, which is integrated with scientific literacy shown in Figure 2.

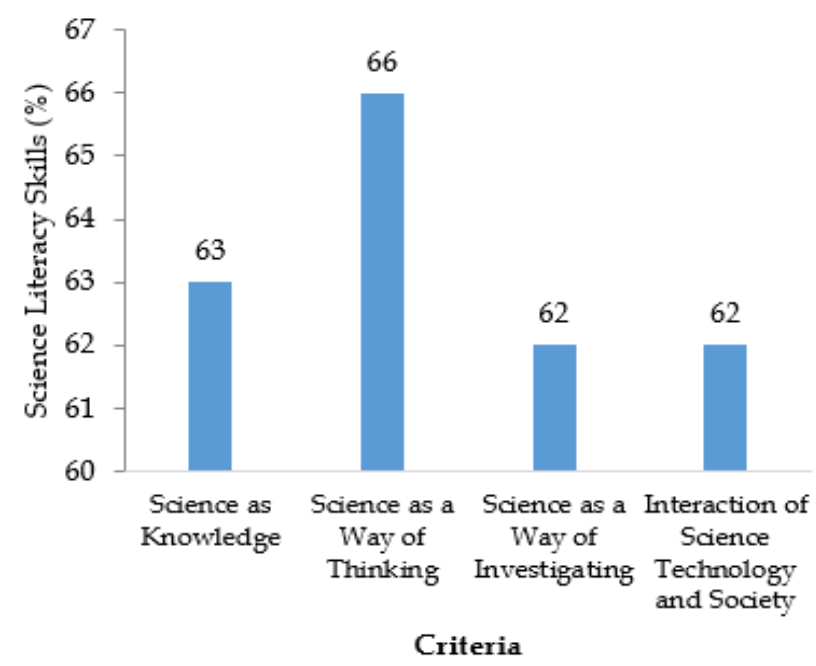

Figure 2. Student Questionnaire Data on Science Literacy Ability

Based on Figure 2, the results of the student questionnaire analysis showed the literacy aspect of mastery of science as knowledge by $63 \%$. The low mastery of this aspect demonstrates the ability of MTs Al Uswah students' ability to understand concepts (Wijayanti \&Basyar, 2016), legal principles, presenting 
hypotheses, theories, and models, Internal and external factors, internal factors that affect student interest in learning and student motivation, while external factors influence the choice of teaching methods and models by teachers, facilities, and the learning environment in the classroom. The possibility of scientific literacy skills in this category only reaches $63 \%$, namely: (1) teachers often teach using formulas not by teaching the concepts, (2) students do not understand the basic concepts taught by the teacher, (3) students do not understand regarding the principles used in science learning, and (4) students do not have knowledge in fact so they cannot present hypotheses in learning which results in students being unable to answer questions based on the knowledge and information they get.

The literacy strategy has been implemented in technology-themed learning to improve the physics literacy of junior high school students related to the application of the concept of Light and Optics, Ultra Sonographer (USG) related to the application of the concept of Sound Waves, and exercises with stationary bicycles and walking-related to the application of the concept of motion (Feranie et al., 2016). Furthermore, web blogging media based on thematically integrated e-portfolio media support students to take advantage of various concepts and demonstrate the ability to connect these concepts with everyday life so as to improve students' scientific literacy (Wijayanti \& Basyar, 2016). So, it can be concluded that the use of learning media can improve students' basic concepts of thinking.

The next aspect of scientific literacy is science as a way of thinking by $66 \%$. The low mastery of this aspect suggests that students rarely study independently at home and are unable to experiment with critical thinking and analyze cause and effect relationships based on facts and evidence to solve problems, explain scientific phenomena, evaluate and interpret measured evidence data (Suryati et al., 2018), and do not describe the proper treatment of scientists who conduct experiments and do not demonstrate inductive and deductive reasoning skills. The scientific literacy ability of students in this category only reached $66 \%$. This shows that students: (1) do not understand the scientific method, (2) are not accustomed to solving problems based on facts and evidence (Nuryanti et al., 2019), (3) are not taught by the teacher to analyze causal relationships, and (4) students are not taught to show their inductive and deductive abilities, (5) are not used to solving problems related to Science (Jufrida et al., 2019). The majority of students have reached scientific literacy, while some students have not met the experimental abilities and basic observation of the scientific method (Murti et al., 2018).
The aspect of scientific literacy as a way of investigating was $62 \%$. The low mastery of this aspect shows that students rarely do the practicum. More time students spent on reading material activities. The lack of practical learning results in students: (1) students cannot answer questions or make practicum reports in the form of graphs, tables, (2) students do not use procedural step designs, (3) cannot carry out experimental activities, and (4) unable to invite students to make calculations.

In the aspect of mastering the competence of the interaction of science, technology, and society, $62 \%$ were generated. The low mastery of this aspect is because students do not know how the use of science and technology in everyday life, cannot show concern for the environment, show the negative effects of science and technology on society, discuss social problems related to science and work in everyday life in the field of science (Wijayanti \& Basyar, 2016). Average scientific literacy in the interaction category between science, environmental criteria, technology, and society lacks with an average percentage of $57.25 \%$ (Rusilowati et al., 2019). This shows that the scientific literacy skills of MTs students are still low.

\section{Conclusion}

Based on the results of the research and discussion above, it can be concluded that students have difficulty learning natural science, the level of interest of students is still low. Teachers have not utilized or developed electronic-based learning media or Android-based mobile learning. The existing learning media have not been maximally used during the learning process. In teaching and learning activities, there is still a great need for the development of learning media that can help students be more interested, active, and motivated in the natural science learning process. The results showed that students needed Android-based mobile learning media. In addition, it is hoped that there will be research on the development of learning media that facilitates students in increasing understanding, problem-solving, and scientific literacy.

\section{Acknowledgments}

This research received funding support from Kemenristek/BRIN, Research Grant Number 28.25.3/UN37/PK.6.8/2021, and Research Grant Tesis Number 13.26.7/UN37/PPK.5.1/2021. We want to thank LP2M Unnes for the support and facilities provided. 


\section{References}

AS, A. S. (2020). Sains Dan Teknologi Dalam AlQur'an. Jurnal Studi Keagamaan, Sosial Dan Budaya, 5(1), 67-69. Retrieved from: http://ejournal.kopertais4.or.id/mataraman/in dex.php/sumbula/issue/view/837.

[Indonesian]

Asrizal, A., Amran, A., Ananda, A., Festiyed, F., \& Sumarmin, R. (2018). The Development of Integrated Science Instructional Materials to Improve Studentsâ€ $€^{\mathrm{TM}}$ Digital Literacy in Scientific Approach. Jurnal Pendidikan IPA Indonesia, 7(4), 442-450. doi:https://doi.org/10.15294/ipii.v7i4.13613

Badarussyamsi, B. (2015). Spiritualitas Sains Dalam Islam: Mengungkap Teologi Saintifik Islam. MIQOT: Jurnal Ilmu-Ilmu Keislaman, 39(2), 255275. https://doi.org/10.30821/miqot.v39i2.17 [Indonesian]

Billah, A., \& Yazid, M. A. (2020). Developing an android-based learning media on human auditory system for junior high school students. Journal of Physics: Conference Series, 1567(4). https://doi.org/10.1088/17426596/1567/4/042003.

Cahyana, U., Paristiowati, M., \& Fauziyah, S. (2018). Development of Android-Based Mobile learning media on Atomic Structure and Periodic Table. IOP Conference Series: Materials Science and Engineering, $\quad 434, \quad 12095$. https://doi.org/10.1088/1757899X/434/1/012095

Feranie, S., Efendi, R., Karim, S., \& Sasmita, D. (2016). Implementation literacy strategies on health technology theme Learning to enhance Indonesian Junior High School Student's Physics Literacy. Journal of Physics Conference Series, 739, $12115 . \quad$ https://doi.org/10.1088/1742$\underline{6596 / 739 / 1 / 012115}$

Haryanto, A., \& Billah, A. (2020). Establishing An Android-Based Integrated Sciences Glossary For Junior High School Students. Journal of Physics: Conference Series, 1567(4), 2-8. https://doi.org/10.1088/17426596/1567/4/042014

Juannita, \& Adhi, B. P. (2017). Pengembangan Media Pembelajaran Sistem Pencernaan Manusia Untuk Kelas 8 Smp Dengan Fitur Augmented Reality Berbasis Android (Studi Kasus: SMPN 7 Depok). Jurnal PINTER, 1(1), 76-81. doi: https://doi.org/10.21009/pinter.1.1.10 [Indonesian]

Jufrida, J., Basuki, F. R., Kurniawan, W., Pangestu, M. D., \& Fitaloka, O. (2019). Scientific literacy and science learning achievement at junior high school. International Journal of Evaluation and Research in Education, 8(4), 630-636. https://doi.org/10.11591/ijere.v8i4.20312

Kusumawardhani, R., Suryati, S., \& Khery, Y. (2019). Pengembangan Media Pembelajaran Berbasis Android Untuk Penumbuhan Literasi Sains Siswa Pada Materi Sistem Periodik Unsur. Hydrogen: Jurnal Kependidikan Kimia, 5(2), 48-56. https://doi.org/10.33394/hjkk.v5i2.1589

[Indonesian]

Liu, M., Horton, L., Lee, J., Kang, J., Rosenblum, J., O'Hair, M., \& Lu, C. W. (2015). Creating a Multimedia Enhanced Problem-Based Learning Environment for Middle School Science: Voices from the Developers. Interdisciplinary Journal of Problem-Based Learning, 8(1), 81-91. https://doi.org/10.7771/1541-5015.1422

Murti, P. R., Aminah, N. S., \& Harjana. (2018). The Analysis of High School Students' Science Literacy Based on Nature of Science Literacy Test (NOSLiT). Journal of Physics: Conference Series, 1097(1), 1-8. https://doi.org/10.1088/17426596/1097/1/012003

Ngabekti, S., Prasetyo, A. P. B., Hardianti, R. D., \& Teampanpong, J. (2019). The Development Of Stem Mobile Learning Package Ecosystem. Jurnal Pendidikan IPA Indonesia, 8(1), 81-88. https://doi.org/10.15294/jpii.v8i1.16905

Nuryanti, A., Kaniawati, I., \& Suwarma, I. R. (2019). Junior High School Students' Scientific Literacy on Earth Science Concept. Journal of Physics: Conference Series, 1157(2), 1-5. https://doi.org/10.1088/17426596/1157/2/022044

OECD. (2015). PISA 2015 Framework. Oecd, March 2015, 1-50. https://doi.org/10.1177/0022146512469014

Pratama, C., Kaspul, \& Arsyad, M. (2020). Pengembangan Media Pembelajaran Interaktif Berbasis Aplikasi Android Pada Konsep Sistem Pernapasan Manusia Jenjang SMA. Bioeduin, 10(2), 16-23. doi: https://doi.org/10.15575/bioeduin.v10i2.12086 [Indonesian]

Rusilowati, A., Supriyadi, Dwijananti, P., \& Khabibah, E. A. N. (2019). Scientific Literacy of Secondary School Students' Related the Global Warming Subject. Journal of Physics: Conference Series, 1387(1). $\quad$ https://doi.org/10.1088/17426596/1387/1/012048.

Sajidan, M., Billah, A., Masykuri, M., \& Sarwanto. (2020). The development of android-based science learning media on human eyes topic. Journal of Physics: Conference Series, 1567, 42026. https://doi.org/10.1088/1742- 
6596/1567/4/042026.

Sugiyono. (2019). Metode Penelitian Pendidikan. Alfabeta. [Indonesian]

Suryawati, E., Natalina, M., Nadia, N., \& Deswati, D. (2018). The Implementation of 5e Learning Cycle Model on the Topic 'Structure and Function of Plants" to Improve the Scientific Literacy of the Second Year Students of a Junior High School in Pekanbaru.' International Journal of Educational Best Practices, 2(2), 26-33. doi: http://dx.doi.org/10.31258/ijebp.v2n2.p26-33

Wibawa, S. C., Nuryana, I. K. D., Prismana, I., Dermawan, D. A., Manyu, A., Frianto, A., Rahmadyanti, E., Susetyaningsih, D. E., Shofiyah, N., Yusron, R. M., \& Mashudi. (2020). Designing of Android Based Learning (Mobile Learning) for Multidiscipline Students. Journal of Physics: Conference Series, 1569(2), 1-5. https:// doi.org/10.1088/1742$\underline{6596 / 1569 / 2 / 022015}$

Wijayanti, A., \& Basyar, M. A. K. (2016). The development of thematic-integrated E-portfolio me-dia web blog based to increase the scientific literacy of elementary teacher education program's student. Jurnal Pendidikan IPA Indonesia, 5(2), 284-290. https:// doi.org/10.15294/jpii.v5i2.7684

Yaqin, A. (2020). Integrasi Ayat-Ayat Al-Qur'an Dalam Pembelajaran Sains (Biologi) Berdasarkan Pemikiran Ian G. Barbour. SPEKTRA: Jurnal Kajian Pendidikan Sains, 6(1), 78. https://doi.org/10.32699/spektra.v6i1.119 [Indonesian] 